ISSN 2083-3725

Volume 10, No. 4, 2017
Authors' contribution/

Wkład autorów:

A. Zaplanowanie badań/

Study design

B. Zebranie danych/

Data collection

Statistical analysis

D. Interpretacja danych/

Data interpretation

E. Przygotowanie tekstu/

Manuscript preparation

F. Opracowanie

piśmiennictwa/

Literature search

G. Pozyskanie funduszy/

Funds collection
C. Analiza statystyczna/

\section{ECOLOGICAL ACTIVITY AS PART OF THE CORPORATE SOCIAL RESPONSIBILITY CONCEPT AREA (BASED ON THE EXAMPLE OF AGRICULTURAL ENTERPRISES IN RURAL AREAS)}

\section{AKTYWNOŚĆ PROEKOLOGICZNA JAKO OBSZAR KONCEPCJI CORPORATE SOCIAL RESPONSIBILITY (NA PRZYKŁADZIE PRZEDSIĘBIORSTW AGROBIZNESU Z OBSZARÓW WIEJSKICH)}

\author{
Marcin Ratajczak $^{1(\mathrm{~A}, \mathrm{~B}, \mathrm{C}, \mathrm{E}, \mathrm{G})}$, Jan Wołoszyn ${ }^{2(\mathrm{D}, \mathrm{E}, \mathrm{F}, \mathrm{G})}$
}

${ }^{1}$ Warsaw University of Life Sciences

Szkoła Główna Gospodarstwa Wiejskiego w Warszawie

${ }^{2}$ Pope John Paul II State School of Higher Education in Biała Podlaska

Państwowa Szkoła Wyższa im. Papieża Jana Pawła II w Białej Podlaskiej

Ratajczak M., Wołoszyn J. (2017), Ecological activity as part of the corporate social responsibility concept area (based on the example of agricultural enterprises in rural areas)/ Aktywność proekologiczna jako obszar koncepcji Corporate Social Responsibility (na przykładzie przedsiębiorstw agrobiznesu z obszarów wiejskich). Economic and Regional Studies, Vol. 10, No. 4, pp. 43-53.

https://doi.org/10.29316/ers-seir.2017.33

\section{ORIGINAL ARTICLE}

JEL code: 012, 013, 018.

Subject and purpose of work: The purpose of this article is to show the results of the analysis of the involvement of micro-, small and medium-sized agribusiness enterprises operating in rural areas with reference to the issues of social responsibility in protection of natural environment.

Materials and methods: Research on entrepreneurs' views on CSR activities was conducted at the turn of 2016 and 2017 and included 212 micro (0-9 persons), small (10-49 employees) and medium (50-249 employees) agribusiness enterprises conducting business activity in the rural areas of the Wielkopolska province.

Submitted:

province.

Results. The conducted research has confirmed the common view that micro enterprises show little 位 is slightly better for small and medium enterprises.

Conclusions: Pro-environmental activities, especially in the agribusiness sector, should be promoted, highlighting the range of benefits that can be achieved through these activities, such as improving relationships with the local community, increasing employees' motivation, and increasing customers' loyalty.

Tables: 2

Figures: 9

References: 12

Keywords: CSR concept, environment, agribusiness, rural areas

ORYGINALNY ARTYKUŁ NAUKOWY

Klasyfikacja JEL: 012, 013, 018.

Zgłoszony:

Lipiec 2017

Zaakceptowany:

Wrzesień 2017

Tabele: 2

Rysunki: 9

Literatura: 12

\section{Streszczenie}

Przedmiot i cel pracy: Celem artykułu jest przedstawienie wyników analizy zaangażowania mikro, małych i średnich przedsiębiorstw agrobiznesu prowadzących swoją działalność na obszarach wiejskich w odniesieniu do zagadnień społecznej odpowiedzialności w zakresie ochrony środowiska naturalnego. Materiały i metody: Badania dotyczące opinii przedsiębiorców na temat podejmowanych działań w zakresie społecznej odpowiedzialności zostały przeprowadzone na przełomie 2016 oraz 2017 roku i obejmowały 212 mikro (0-9 osób), małych (10-49 zatrudnionych) i średnich (50-249 pracowników) przedsiębiorstw agrobiznesu prowadzących działalność gospodarczą na obszarach wiejskich województwa wielkopolskiego.

Wyniki: Przeprowadzone badania potwierdziły dość często spotykaną opinię, iż mikro przedsiębiorstwa wykazują znikome zainteresowanie wdrażaniem podstawowych standardów społecznej odpowiedzialności w obszarze „środowisko naturalne”. Nieco lepiej wygląda sytuacja w odniesieniu do przedsiębiorstw małych i średnich.

Wnioski: Należy promować $w$ coraz większym zakresie działania prośrodowiskowe, zwłaszcza w firmach z sektora agrobiznesu, podkreślając szereg korzyści możliwych do osiągnięcia dzięki tym działaniom, takich jak poprawa relacji ze społecznością lokalną, większa motywacja pracowników oraz zwiększenie lojalności klientów.

Słowa kluczowe: koncepcja CSR, środowisko naturalne, agrobiznes, obszary wiejskie

Address for correspondence/ Adres korespondencyjny: dr Marcin Ratajczak (ORCID 0000-0001-5158-6505), Szkoła Główna Gospodarstwa Wiejskiego w Warszawie, Wydział Nauk Ekonomicznych, ul. Nowoursynowska 166, 02-787 Warszawa, Polska; tel. +48 504615 265; e-mail: marcin_ratajczak@sggw.pl; dr hab. Jan Wołoszyn, prof., Państwowa Szkoła Wyższa im. Papież Jana Pawła II w Białej Podlaskiej, Wydział Nauk Ekonomicznych i Technicznych, ul. Sidorska 95/97, 21-500 Biała Podlaska, Polska; e-mail: j.woloszyn@dydaktyka.pswbp.pl;

Journal indexed in/ Czasopismo indeksowane w: AgEcon Search, AGRO, BazEkon, Index Copernicus Journal Master List, ICV 2016: 92,91; Polish Ministry of Science and Higher Education 2016: 9 points/ AgEcon Search, AGRO, BazEkon, Index Copernicus Journal Master List ICV 2016: 92.91; Ministerstwie Nauki i Szkolnictwa Wyższego 2016: 9 punktów. Copyright: (C) 2017 Pope John Paul II State School of Higher Education in Biała Podlaska, Marcin Ratajczak, Jan Wołoszyn. All articles are distributed under the terms of the Creative Commons Attribution-NonCommercial-ShareAlike 4.0 International (CC BY-NC-SA 4.0) License (http://creativecommons.org/licenses/by-nc-sa/4.0/), allowing third parties to copy and redistribute the material in any medium or format and to remix, transform, and build upon the material, provided the original work is properly cited and states its license. 


\section{Introduction}

Over the past several years, the foregoing view on the business role in the market economy deriving from classical economics has undergone a deep reorientation. The view of Milton Friedman, laureate of the Bank of Sweden named after Alfred Nobel in the field of economics in 1976, that in the market economy the company's resources and energy should be used to multiply profits, is not currently widely accepted. Stakeholders, but also some entrepreneurs realize that no organization will succeed in business unless it is socially responsible (Lewicka-Strzałecka 2006).

Hence, there has been a growing interest in the concept of Corporate Social Responsibility (CSR), highlighting the role of activities in organizations focused not only on financial gain and economic aspects but also on the social interest and the natural environment (Ratajczak, Wołoszyn, Stawicka 2012).

The issue of Corporate Social Responsibility is also of interest to the European Commission, which sees this responsibility not only as an obligation originating from legal requirements and binding agreements, but as voluntary activities. It encourages businesses to take into account in their activities not only the economic factor but also the social and environmental issues (Green Paper, 2001).

A full description of the activities available for organizations in the scope of environmental responsibilities is contained in ISO 26000 standard, which is an international standard for the social responsibility of all organizations in various areas of their activity, including activities that negatively affect the environment. This standard, which is of universal nature, is a set of voluntary guidelines that should be applied by all organizations (Ocieczek, Gajdzik 2010).

In particular, this is important for companies operating in the area of agribusiness, most often considered as a broad economic activity, including production and services in the area of:

- manufacturing means of production and provision of services necessary for agriculture or processing agricultural raw materials,

- sourcing (production) of raw materials (farming, fishing, fishery, forestry);

- processing of agricultural, food, and non-food raw materials,

- storage of food and non-food products produced from agricultural raw materials,

- refining, sorting, transport, wholesale and retail sale,

- export, import and marketing services (Kapusta 2006).

The significance of the discussed problem lies in fact that it is the agribusiness, as a substitute for the national economy, that meets the primary needs of mankind that condition its continued functioning and development (Smędzik 2009). Therefore, the way of manufacturing, storage, storing, refining and transport of food and non-food products is so important. It is influenced by the fact that consumers

\section{Wstęp}

W ciągu ostatnich kilkunastu lat dotychczasowe zapatrywanie na rolę biznesu $\mathrm{w}$ gospodarce rynkowej wywodzące się z klasycznej ekonomii uległo głębokiemu przeorientowaniu. Pogląd Miltona Friedmana, laureata Banku Szwecji im. Alfreda Nobla w dziedzinie ekonomii z 1976 roku, iż w gospodarce rynkowej przedsiębiorstwa swoje zasoby i całą energię powinny wykorzystać na pomnożenie zysków, nie jest obecnie powszechnie akceptowany. Interesariusze, ale też niektórzy przedsiębiorcy zdają sobie sprawę, że żadna organizacja nie odniesie sukcesu w biznesie, jeżeli nie będzie odpowiedzialna społecznie (Lewicka-Strzałecka 2006).

Stąd, od pewnego czasu rośnie zainteresowanie koncepcją społecznej odpowiedzialności biznesu (Corporate Social Responsibility - CSR) podkreślającej rolę działań w organizacji zorientowanych nie tylko na zysk finansowy i aspekty ekonomiczne, ale również na interes społeczny i środowisko przyrodnicze (Ratajczak, Wołoszyn, Stawicka 2012).

Zagadnieniem społecznej odpowiedzialności przedsiębiorstw interesuje się również Komisja Europejska, która odpowiedzialność tą widzi nie tylko jako obowiązek wynikający z wymagań prawnych i obowiązujących umów, lecz jako działania dobrowolne. Zachęca więc przedsiębiorstwa, aby w swoim działaniu uwzględniały nie tylko czynnik ekonomiczny, lecz także zagadnienia społeczne i ekologiczne (Green Paper, 2001).

Pełny opis możliwych działań organizacji w obszarze odpowiedzialności za stan środowiska naturalnego zawiera norma ISO 26000, będąca międzynarodowym standardem społecznej odpowiedzialności wszystkich organizacji w różnych obszarach ich aktywności, w tym działalności mającej negatywny wpływ na stan środowiska naturalnego. Norma ta, mająca charakter uniwersalny, jest zbiorem dobrowolnych wytycznych, które powinny być stosowane przez wszystkie organizacje (Ocieczek, Gajdzik 2010).

Szczególnie jest to ważne w odniesieniu do przedsiębiorstw prowadzących swoją działalność w obszarze agrobiznesu, traktowanego najczęściej jako szeroka działalność gospodarcza obejmująca produkcję i usługi w zakresie:

- wytwarzania środków produkcji i świadczenia usług niezbędnych dla rolnictwa oraz przetwórstwa surowców rolniczych,

- pozyskiwania (wytwarzania) surowców (rolnictwo, rybołówstwo, rybactwo, leśnictwo),

- przetwórstwa surowców rolniczych żywnościowych i nieżywnościowych,

- składowania produktów żywnościowych i nieżywnościowych powstałych $\mathrm{z}$ surowców rolnych,

- uszlachetniania, sortowania, transportu oraz sprzedaży hurtowej i detalicznej,

- eksportu i importu oraz usług marketingowych (Kapusta 2006).

Znaczenie omawianego problemu jest o tyle istotne, że to właśnie agrobiznes jako substytut gospodar- 
are increasingly paying attention not only to the price but rather to the quality of products. The role of social responsibility in agribusiness is becoming increasingly important (Garriga, Mele 2004).

Unfortunately, many manufacturers and service providers still do not pay due attention to the protection of natural environment in the field of their activities (Ratajczak 2016), although the previously mentioned ISO 26000 standard, the ISO 14001 standard (EN ISO 14001: 2004 item 3.12) as well as the Environmental Protection Law (Journal of Laws of 2001, No. 62, item 627) oblige them to do so.

In accordance with the provisions of the mentioned Act and the ISO standards, the responsibility of the enterprises for ecology should be related to the successive elimination of economic operations that are harmful to the natural environment and which adversely affect human health. Environmentalfocused activity is also intended to restore the environment to its original condition (Banerjee 2008). Therefore, enterprises should have a defined environmental policy that is treated as general intents and principles related to the whole of their business, constituting a framework for the individual's actions that enable to set environmental objectives and tasks. This policy should be defined to correspond to the scope and scale of the production or services (Nahotko 2002).

The aim of this article is to present the results of the analysis of the involvement of micro-, small and medium-sized agribusiness enterprises operating in rural areas with regard to the issues of protection of natural environment.

The following activities of the examined economic entities, connected with their influence on the condition of the natural environment, were analysed:

- development, implementation and documentation of the environmental policy,

- taking positive pro-environmental measures and their diversity.

The research was conducted in the Wielkopolska province to determine how agribusiness enterprises from the region characterized by a high intensity of agricultural output and a large concentration of enterprises directly or indirectly related to this production address the idea of social responsibility.

\section{Material and methods}

Research on views of entrepreneurs on CSR activities (specifically, the natural environment) was conducted at the turn of 2016 and 2017 and included 212 micro (0-9 persons), small (10-49 employees) and medium (50-249 employees) agribusiness enterprises conducting business activity in the rural areas of the Wielkopolska province. ki narodowej zaspokaja pierwotne potrzeby ludzkości warunkujące jej dalsze funkcjonowanie i rozwój (Smędzik 2009). Dlatego sposób wytwarzania, przetwarzania, przechowywania, uszlachetniania i transportu produktów żywnościowych oraz nieżywnościowych jest tak bardzo ważny. Wpływa to na to, że konsumenci coraz częściej zwracają uwagę nie tylko na cenę, ale właśnie na jakość produktów. Rola społecznej odpowiedzialności w agrobiznesie nabiera więc coraz większego znaczenia (Garriga, Mele 2004).

Niestety wielu producentów i usługodawców nadal nie przywiązuje należytej wagi do ochrony środowiska naturalnego w zakresie swojej działalności (Ratajczak 2016), choć zarówno wymieniona wcześniej norma ISO 26000, norma ISO 14001 (EN ISO 14001:2004 pkt 3.12) jak też Ustawa Prawo ochrony środowiska (Dz.U. 2001 r., Nr 62, Poz. 627) ich do tego obligują.

Zgodnie z zapisami wymienionej Ustawy i norm ISO odpowiedzialność przedsiębiorstw za ekologię powinna dotyczyć sukcesywnego eliminowania działań gospodarczych szkodliwych dla środowiska przyrodniczego i wpływających negatywnie na zdrowie ludzi. Działalność ukierunkowana na ekologię ma też za zadanie przywracanie środowiska do stanu pierwotnego (Banerjee 2008). Dlatego też przedsiębiorstwa winny posiadać zdefiniowaną politykę środowiskową traktowaną jako ogół zamierzeń i zasad związanych z całością prowadzonej działalności, stanowiącą ramy działań prowadzonych przez jednostkę, umożliwiającą ustalanie celów i zadań środowiskowych. Polityka ta powinna być zdefiniowana tak, aby odpowiadała zakresowi i skali prowadzonej produkcji lub świadczonych usług (Nahotko 2002).

Celem artykułu jest przedstawienie wyników analizy zaangażowania mikro, małych i średnich przedsiębiorstw agrobiznesu prowadzących swoją działalność na obszarach wiejskich w odniesieniu do zagadnień społecznej odpowiedzialności w zakresie ochrony środowiska naturalnego.

Analizie poddano następujące aktywności badanych podmiotów gospodarczych związana z ich wpływem na stan środowiska naturalnego:

- opracowywanie, wdrażanie i dokumentowanie polityki środowiskowej,

- podejmowanie pozytywnych działań prośrodowiskowych oraz ich zróżnicowanie.

Badania przeprowadzono na terenie województwa wielkopolskiego, aby określić, jak do idei społecznej odpowiedzialności podchodzą przedsiębiorstwa agrobiznesu z regionu charakteryzującego się wysoką intensywnością produkcji rolniczej i dużą koncentracją przedsiębiorstw bezpośrednio lub pośrednio związanych z tą produkcją.

\section{Materiał i metody}

Badania dotyczące opinii przedsiębiorców na temat podejmowanych działań w zakresie społecznej odpowiedzialności (dokładnie obszaru środowiska naturalnego) zostały przeprowadzone na przełomie 2016 oraz 2017 roku i obejmowały 212 mikro (0-9 osób), małych (10-49 zatrudnionych) i średnich (50-249 pracowników) przedsiębiorstw agrobiznesu 
The research was conducted by the diagnostic survey method, and the basic research tool was an electronic questionnaire addressed to the examined entities. The detailed contact database used in the research was purchased by the authors from the Central Statistical Office. The survey was sent to all agribusiness entities conducting activity in the examined province (directed to the owners of these companies) - 212 questionnaires were filled fully correctly. The material obtained in this way was subjected to an analysis which had mathematical and statistical nature. An arithmetic mean, test of independence of $\chi^{2}$, Tschuprow's $T$ correlation coefficient, and Pearson's contingency coefficient (adjusted and ordinary) were applied.

Small enterprises dominated the examined population - they constituted $71.7 \%$, microenterprises $26.7 \%$ respectively, while medium entities were $1.6 \%$. Men owned $54.7 \%$ of the examined companies, while women owned $45.3 \%$ of the business entities in the agribusiness sector.

The structure of the owners of the examined enterprises according to their education was favourable. Entrepreneurs from the half of companies had higher education - this is certainly a positive phenomenon, considering the tendency of migration of educated people from rural areas to large urban agglomerations. More than $43 \%$ of respondents had a secondary education - the age range was dominated by people aged 46-55 (almost 48\%). The remaining respondents were characterized by education at the basic vocational level and accounted for about $2 \%$ of the examined population (clear dominance of men over 56 years).

The figure below shows the structure of the examined rural entrepreneurs according to the section of the economy in which they operated. prowadzących działalność gospodarczą na obszarach wiejskich województwa wielkopolskiego.

Badania przeprowadzono metodą sondażu diagnostycznego, a podstawowym narzędziem badawczym był elektroniczny kwestionariusz ankiety skierowany do badanych podmiotów. Szczegółowa baza danych teleadresowych wykorzystana w badaniach została zakupiona przez autorów z Głównego Urzędu Statystycznego. Ankieta została wysłana do wszystkich podmiotów agrobiznesu prowadzących działalność w badanym województwie (skierowana została do właścicieli tych firm) - w pełni poprawnie zostało wypełnionych 212 ankiet. Pozyskany w ten sposób materiał poddano analizie, która miała charakter matematyczno - statystyczny. Wykorzystano przy tym średnią arytmetyczną, test niezależności $\chi^{2}$, współczynnik zbieżności $T$ Czuprowa oraz współczynnik kontyngencji C Pearsona (skorygowany i zwykły).

W analizowanej populacji dominowały małe firmy - stanowiły $71,7 \%$, przedsiębiorstwa mikro odpowiednio $26,7 \%$, z kolei podmioty średnie $1,6 \%$. Mężczyźni byli właścicielami 54,7\% analizowanych przedsiębiorstw, a kobiety $45,3 \%$ podmiotów gospodarczych z sektora agrobiznesu.

Korzystnie prezentowała się struktura właścicieli badanych przedsiębiorstw według ich wykształcenia. Przedsiębiorcy z połowy firm posiadali wykształcenie wyższe - jest to na pewno zjawisko pozytywne biorąc pod uwagę tendencję migracji osób wykształconych ze wsi do dużych aglomeracji miejskich. Ponad $43 \%$ ankietowanych posiadało wykształcenie średnie - przedział wiekowy zdominowany był przez osoby w wieku 46-55 lat (prawie 48\%). Pozostali badani charakteryzowali się wykształceniem na poziomie zasadniczym zawodowym i stanowili około $2 \%$ badanej populacji (wyraźna dominacja mężczyzn powyżej 56 lat).

Na poniższym rysunku przedstawiona jest struktura badanych przedsiębiorców wiejskich według sekcji gospodarki, w której prowadzili działalność.

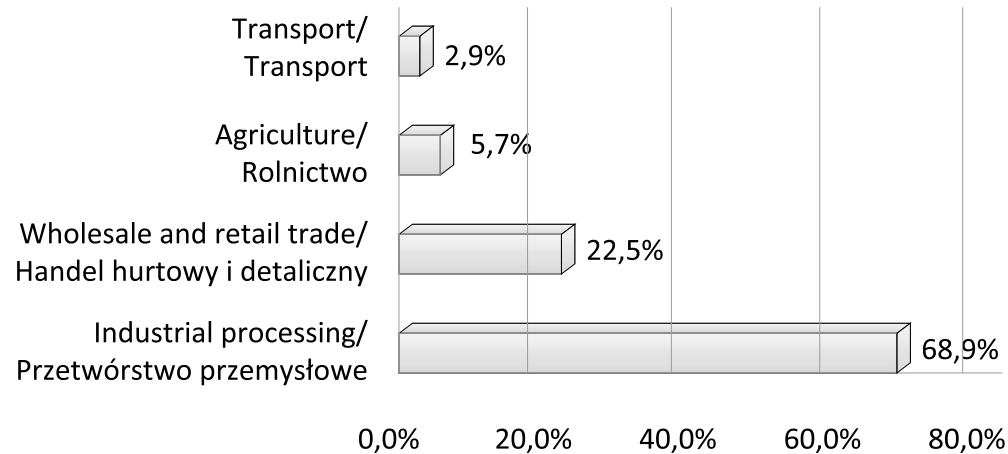

Figure 1. Structure of the examined enterprises according to the section of economy (\%)

Rysunek 1. Struktura badanych przedsiębiorstw według sekcji gospodarki (\%)

Source: own elaboration.

Źródło: badania własne.

Almost $69 \%$ of respondents were active in the industrial processing sector, which is typical for small and medium-sized agribusiness companies on a national level, especially in rural areas. Every fifth of the respondents was engaged in wholesale and retail
Prawie 69\% ankietowanych prowadziła działalność w sekcji przetwórstwa przemysłowego, co jest charakterystyczne dla małych i średnich firm agrobiznesu w skali kraju, a zwłaszcza na terenach wiejskich. Co piąty badany zajmował się handlem 
trade, which resulted from the frequent location of economic entities in the rural areas near large urban agglomerations (distribution and sale of offered goods), especially in the area of Poznań, Konin, Kalisz and Piła. The remaining two sections, agriculture and transport, represent for approximately $8.5 \%$ in the structure of the examined entrepreneurs.

The subject of the research were also the legal forms of the examined business entities from rural areas (Figure 2). hurtowym i detalicznym, co wynikało z częstego lokalizowania podmiotów gospodarczych na obszarach wiejskich $w$ pobliżu dużych aglomeracji miejskich (dystrybucja i sprzedaż oferowanych towarów), zwłaszcza w okolicach Poznania, Konina, Kalisza i Piły. Pozostałe dwie sekcje, rolnictwo oraz transport, stanowiły około $8,5 \%$ w strukturze badanych przedsiębiorców.

Przedmiotem badań były także formy prawne, jakie posiadały badane podmioty gospodarcze z obszarów wiejskich (rysunek 2).

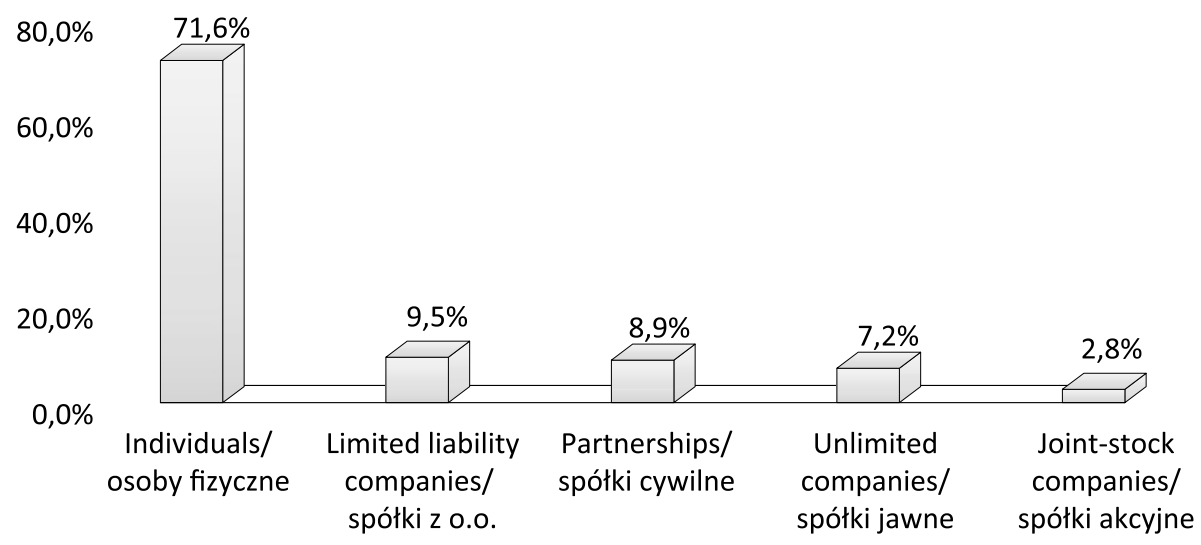

Figure 2. Structure of examined companies by the legal form (\%) Rysunek 2. Struktura badanych firm według formy prawnej (\%) Source: own elaboration.

Źródło: badania własne.

The majority of the examined enterprises (almost $72 \%$ ) functioned as natural legal persons conducting business activity - this form is also most frequently encountered on the scale of the whole country in rural areas. In other cases, these entities were registered as private limited liability companies, partnership (every eleventh business entity) and unlimited companies (about $7 \%$ of the examined population).

\section{Results of own research}

Results of the research conducted among small and medium-sized entrepreneurs operating in rural areas show relatively little interest in environmental policy actions (Figure 3). About 38\% of respondents do not take pro-ecological measures and do not create solutions in the environmental realm. Every fourth respondent indicated that the company has implemented specific environmental solutions and it was accompanied by documented, realistic and measurable goals. However, over $34 \%$ of the owners refer these activities only to the pro-environmental sensitivity, i.e. promoting knowledge in this field and raising the awareness of environmental stakeholders on the aspect of environment protection.
Najwięcej badanych przedsiębiorstw (prawie $72 \%$ ) funkcjonowało jako osoby fizyczne prowadzące działalność gospodarczą - forma ta jest również najczęściej spotykana w skali całego kraju na terenach wiejskich. W pozostałych przypadkach podmioty te były zarejestrowane jako spółki z ograniczona odpowiedzialnością, cywilne (co jedenasty podmiot gospodarczy) oraz spółki jawne (około 7\% badanej populacji).

\section{Wyniki badań własnych}

Wyniki badań przeprowadzonych wśród małych i średnich przedsiębiorców prowadzących działalność na obszarach wiejskich pokazują stosunkowo małe zainteresowanie działaniami $\mathrm{w}$ zakresie polityki środowiskowej (rysunek 3). Około 38\% ankietowanych nie podejmuje żadnych działań proekologicznych i nie tworzy rozwiązań w zakresie środowiskowym. Co czwarty badany wskazał, że $\mathrm{w}$ przedsiębiorstwie wdrożono konkretne rozwiązania środowiskowe i towarzyszą temu udokumentowane, realne i mierzalne cele. Natomiast ponad 34\% właścicieli działania te odnosi tylko do wrażliwości prośrodowiskowej, czyli promowania wiedzy z tego zakresu oraz uwrażliwiania interesariuszy na aspekt ochrony środowiska. 


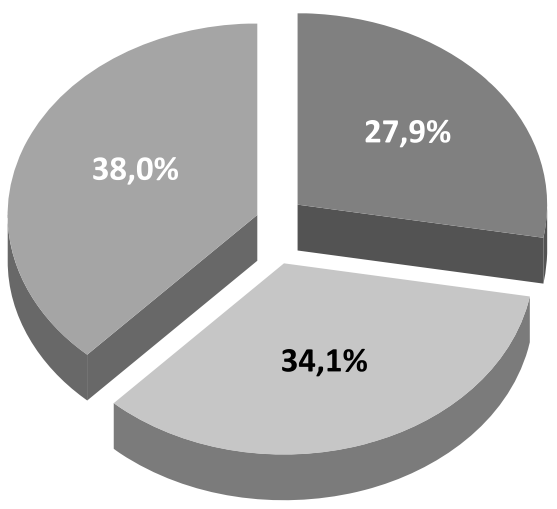

Yes, it is accompanied by documented and measurable goals/

tak, towarzyszą jej udokumentowane i mierzalne cele

Yes, but it refers to the pro-environmental sensitivity/

tak, ale odnosi się do wrażliwości prośrodowiskowe

No, there is no actions in this regard/

nie, brak jest działań w tym kierunku

Figure 3. Implementation of the environmental policy in examined agribusiness enterprises (\%)

Rysunek 3. Wdrażanie polityki środowiskowej w badanych przedsiębiorstwach agrobiznesu (\%)

Source: own elaboration.

Źródło: badania własne.

In order to investigate the statistical independence of the education of business owners from their implementation of environmental policy, the independence test $\chi^{2}$ was conducted, which showed that the analysed variables are mutually dependent (Table 1). Documented and measurable environmental policy objectives were executed by owners with higher education, and the proenvironmental sensitivity was mainly promoted by the people with basic vocational education. On the other hand, a clear lack of action in this direction occurred in entrepreneurs with secondary education. The calculated coefficients have shown that the strength of relationship between these features is moderate.

It was also determined to establish statistical independence between the activity section and the
W celu zbadania statystycznej niezależności pomiędzy wykształceniem właścicieli przedsiębiorstw a wdrażaniem przez nich polityki środowiskowej przeprowadzono test niezależności $\chi^{2}$, który pokazał, że analizowane zmienne są wzajemnie zależne (tabela 1). Udokumentowane i mierzalne cele w zakresie polityki środowiskowej były realizowane przez właścicieli z wykształceniem wyższym, a wrażliwość prośrodowiskowa była głównie promowana przez osoby z wykształceniem zasadniczym zawodowym. Z kolei wyraźny brak działań w tym kierunku miał miejsce u przedsiębiorców z wykształceniem średnim. Obliczone współczynniki pokazały, że siła zależności miedzy tymi cechami jest umiarkowana.

Postarano się także określić statystyczną niezależność pomiędzy sekcją działalności a opracowaniem oraz stosowaniem polityki środowiskowej - test

Table 1. Definition of statistical independence between the education of the owners of the examined enterprises and the development and application of the environmental policy

Tabela 1. Określenie statystycznej niezależności pomiędzy wykształceniem właścicieli badanych przedsiębiorstw a opracowaniem i stosowaniem polityki środowiskowej

\begin{tabular}{|c|c|}
\hline \multicolumn{2}{|c|}{ TEST OF INDEPENDENCE $\chi^{2} /$ TEST NIEZALEŻNOŚCI $\chi^{2}$} \\
\hline \multicolumn{2}{|c|}{$\begin{array}{c}\text { Hypotheses/Hipotezy: } \\
\mathrm{H}_{0} \text { : [the variables examined are mutually independent]/ } \\
\text { [badane zmienne są wzajemnie niezależne] } \\
\mathrm{H}_{1} \text { : [the variables examined are not mutually independent]/ } \\
\text { [badane zmienne nie są wzajemnie niezależne] }\end{array}$} \\
\hline \multicolumn{2}{|c|}{$\begin{array}{l}\qquad X^{2}=14.74>X_{\alpha}^{2}=10.87 \\
\text { therefore we reject the hypothesis } \mathrm{H}_{0} \text { for } \mathrm{H}_{1} \text { at } \alpha=0.05 / \\
\text { zatem odrzucamy hipotezę } \mathrm{H}_{0} \text { na rzecz } \mathrm{H}_{1} \text { przy } \alpha=0,05\end{array}$} \\
\hline $\begin{array}{l}\text { Tschuprow’s T correlation coefficient/ } \\
\text { Współczynnik zbieżności T Czuprowa }\end{array}$ & $\mathrm{Txy}=0.53$ \\
\hline $\begin{array}{c}\text { Pearson’s contingency coefficient - ordinary/ } \\
\text { Współczynnik kontyngencji C Pearsona - zwykły }\end{array}$ & $\mathrm{Cxy}=0.66$ \\
\hline $\begin{array}{l}\text { Pearson's coefficient of contingency } C \text { - adjusted/ } \\
\text { Współczynnik kontyngencji } C \text { Pearsona - skorygowany }\end{array}$ & skorCxy $=0.77$ \\
\hline \multicolumn{2}{|c|}{$\begin{array}{c}\text { Variable X: Education of business owners/ } \\
\text { Zmienna X: Wykształcenie właścicieli przedsiębiorstw }\end{array}$} \\
\hline \multicolumn{2}{|c|}{$\begin{array}{l}\text { Variable Y: Development and application of environmental policy/ } \\
\text { Zmienna Y: Opracowanie i stosowanie polityki środowiskowej }\end{array}$} \\
\hline
\end{tabular}

Source: own elaboration.

Źródło: badania własne. 
development and application of environmental policy - the test of independence $\chi^{2}$ showed that the variables tested are not mutually independent (Table 2). Documented and measurable goals in environmental policy were mainly implemented by manufacturing industry companies. Sensitization of stakeholders to environmental protection primarily took place in the economic entities from agricultural and commercial section. It is also worth stressing that the calculated coefficients have shown a strong correlation between these characteristics, in particular this is shown by a high value of the adjusted $C$ Pearson contingency coefficient.

Table 2. Definition of statistical independence between the activity section (Polish Classification of Activities) and the development and application of environmental policy

Tabela 2. Określenie statystycznej niezależności pomiędzy sekcją działalności (PKD) a opracowaniem i stosowaniem polityki środowiskowej

\begin{tabular}{|c|c|}
\hline \multicolumn{2}{|c|}{ TEST OF INDEPENDENCE $\chi^{2} /$ TEST NIEZALEŻNOŚCI $\chi^{2}$} \\
\hline \multicolumn{2}{|c|}{$\begin{array}{c}\text { Hypotheses/Hipotezy: } \\
\mathrm{H}_{0}: \text { [the variables examined are mutually independent]/ } \\
\text { [badane zmienne są wzajemnie niezależne] } \\
\mathrm{H}_{1} \text { : [the variables examined are not mutually independent]/ } \\
\text { [badane zmienne nie sa wzajemnie niezależne] }\end{array}$} \\
\hline \multicolumn{2}{|c|}{$\begin{array}{l}\qquad X^{2}=22,67>X_{\alpha}^{2}=8,41 \\
\text { therefore we reject the hypothesis } \mathrm{H}_{0} \text { for } \mathrm{H}_{1} \text { at } \alpha=0.05 / \\
\text { zatem odrzucamy hipotezę } \mathrm{H}_{0} \text { na rzecz } \mathrm{H}_{1} \text { przy } \alpha=0,05\end{array}$} \\
\hline $\begin{array}{l}\text { Tschuprow’s } T \text { correlation coefficient/ } \\
\text { Współczynnik zbieżności } T \text { Czuprowa }\end{array}$ & $\mathrm{Txy}=0.60$ \\
\hline $\begin{array}{c}\text { Pearson's contingency coefficient - ordinary/ } \\
\text { Współczynnik kontyngencji C Pearsona - zwykły }\end{array}$ & $\mathrm{Cxy}=0.66$ \\
\hline $\begin{array}{l}\text { Pearson's coefficient of contingency } C \text { - adjusted/ } \\
\text { Współczynnik kontyngencji } C \text { Pearsona - skorygowany }\end{array}$ & skorCxy $=0.76$ \\
\hline \multicolumn{2}{|c|}{$\begin{array}{c}\text { Variable X: Section of activity (Polish Classification of Activities) } \\
\text { Zmienna X: Sekcja działalności (PKD) }\end{array}$} \\
\hline \multicolumn{2}{|c|}{$\begin{array}{l}\text { Variable Y: Development and application of environmental policy/ } \\
\text { Zmienna Y: Opracowanie i stosowanie polityki środowiskowej }\end{array}$} \\
\hline
\end{tabular}

Source: own elaboration.

Źródło: badania własne.

The validity of the above examined test of independence confirmed the summary presented in Figure 4, concerning the implementation of environmental policy according to the section of economy. The results show that documented and measurable goal primarily occurred in manufacturing companies (almost 76\% of answers) and commercial companies (almost half of the indications) - certainly due to the greater pro-environmental requirements of these companies. Pro-environmental sensitivity and related aspects took place to a maximum extent within the agricultural section (almost 37\%). It is worth noting that activities of this type were taken in the smallest range by companies operating in the transport section - more than $66 \%$ of indications on lack of any activities in the environmental area. niezależności $\chi^{2}$ pokazał, że badane zmienne nie są wzajemnie niezależne (tabela 2). Udokumentowane i mierzalne cele w zakresie polityki środowiskowej były realizowane głównie przez firmy z branży przetwórstwa przemysłowego. Uwrażliwianie interesariuszy na ochronę środowiska miało miejsce przede wszystkim w podmiotach gospodarczych z sekcji rolnej i handlowej. Warto także podkreślić, że obliczone współczynniki pokazały silną zależność między tymi skorygowanego współczynnika kontyngencji $C$ Pearsona. cechami, szczególnie pokazuje to wysoka wartość 


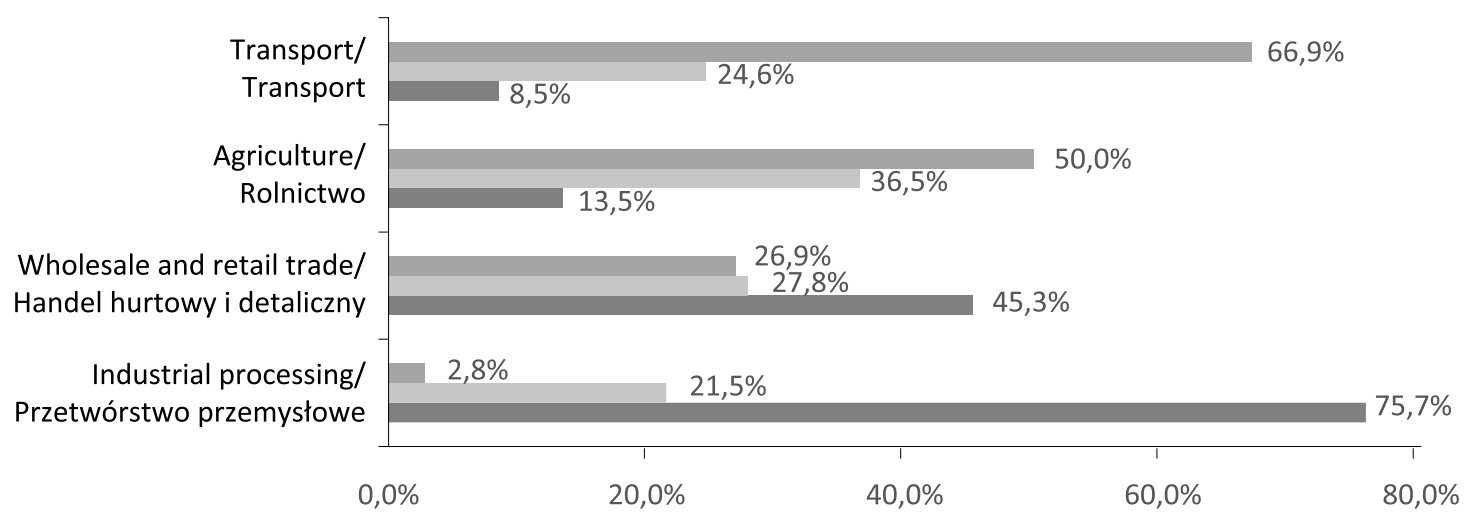

No, there is no actions in this regard/ Nie, brak jest działań w tym kierunku

Yes, but it refers to the pro-environmental sensitivity/ Tak, ale odnosi się do wrażliwości prośrodowiskowej

Yes, it is accompanied by documented and measurable goals/ Tak, towarzyszą jej udokumentowane i mierzalne

Figure 4. Implementing environmental policy by section of economy (\%)

Rysunek 4. Wdrażanie polityki środowiskowej według sekcji gospodarki (\%)

Source: own elaboration.

Źródło: badania własne.

Figure 5 shows the matters of the implementation of environmental policy according to the enterprise size (taking into account the number of employees). Basically, none of these activities are undertaken in micro-businesses - around $88 \%$ of owners claimed they did not do any activities for this purpose.
Na rysunku 5 przedstawione zostały kwestie wdrażania polityki środowiskowej według wielkości przedsiębiorstwa (uwzględniając liczbę osób zatrudnionych). Praktycznie w ogóle takie działania nie mają miejsca w mikroprzedsiębiorstwach - około 88\% właścicieli steiwerdziło, że nie prowadzi żadnych działań w tym kierunku.

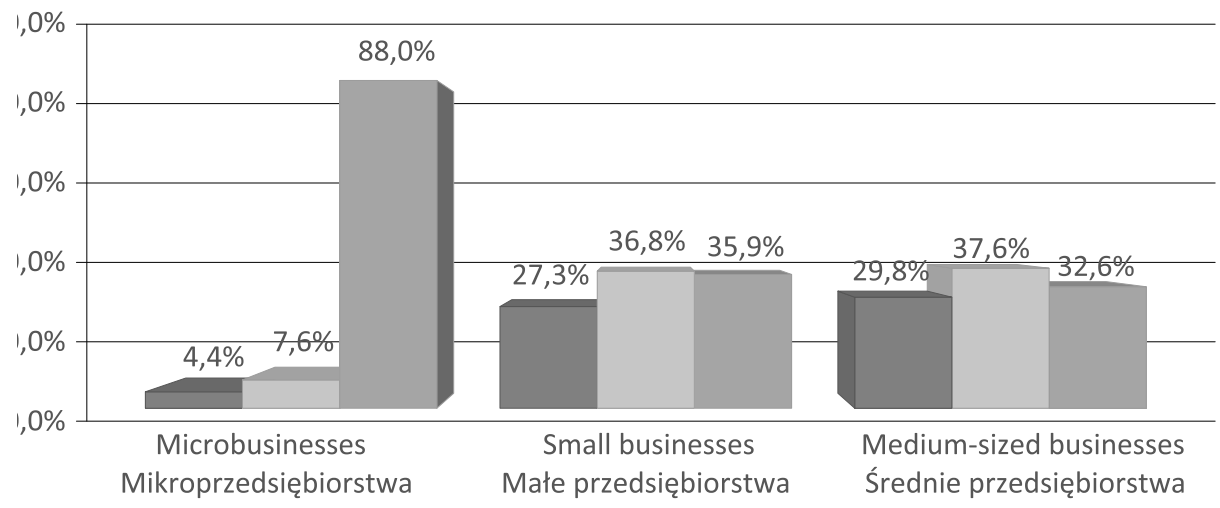

ccompanied by documented and measurable goals/ Tak, towarzyszą jej udokumentowane i mierzalne cele

refers to the pro-environmental sensitivity/ Tak, ale odnosi się do wrażliwości prośrodowiskowej

is no actions in this regard/ Nie, brak jest działań w tym kierunku

Figure 5. Implementation of environmental policy according to the enterprise size (\%)

Rysunek 5. Wdrażanie polityki środowiskowej według wielkości przedsiębiorstwa (\%)

Source: own elaboration.

Źródło: badania własne.

In small and medium-sized businesses, the results are very similar - one in four respondents claimed to conduct activities in the environmental realm that are documented and measurable, and more than $37 \%$ of owners are trying to make their environment more aware of current environmental problems or problems arising from them.
W podmiotach małych oraz średnich wyniki kształtują się bardzo podobnie - co czwarty ankietowany stwierdził, że prowadzi w zakresie środowiskowym działania udokumentowane oraz mierzalne a ponad $37 \%$ właścicieli stara się uwrażliwiać swoje otoczenie na bieżące problemy związane ze środowiskiem naturalnym, czy też problemami z tego wynikającymi. 
More than $36 \%$ of the respondents admitted that they did not implement environmental protection actions, and did not even wonder how their company influenced the environment (Figure 6 ). One in three respondents claimed that they analyse the environment and try to implement pro-environmental solutions, but they take into consideration only aspects closely related to the nature of the company's business. Approximately $31 \%$ of owners declared constant care and analysis of activities of their business entity in the field of environmental protection as well as taking action and concrete solutions in this regard.

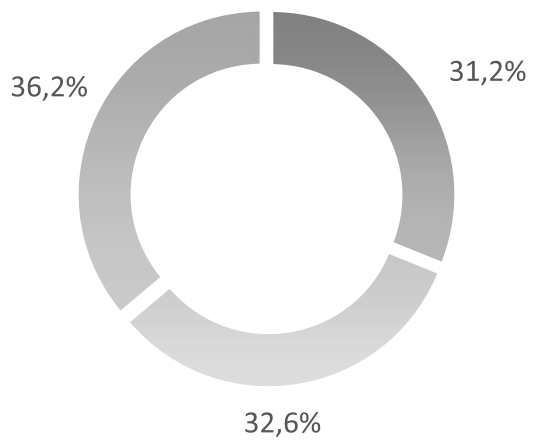

Ponad 36\% badanych przyznało, że nie wdraża działań w kierunku ochrony środowiska naturalnego, a nawet nie zastanawia się, jak ich firma wpływa na środowisko (rysunek 6). Co trzeci ankietowany stwierdził z kolei, że analizuje otoczenie i stara się wprowadzać rozwiązania prośrodowiskowe, ale bierze pod uwagę tylko aspekty ściśle związane z charakterem działalności firmy. Około 31\% właścicieli zadeklarowało stałą troskę i analizę działań swojego podmiotu gospodarczego w zakresie ochrony środowiska a także podejmowanie działań i konkretnych rozwiązań w tym zakresie.

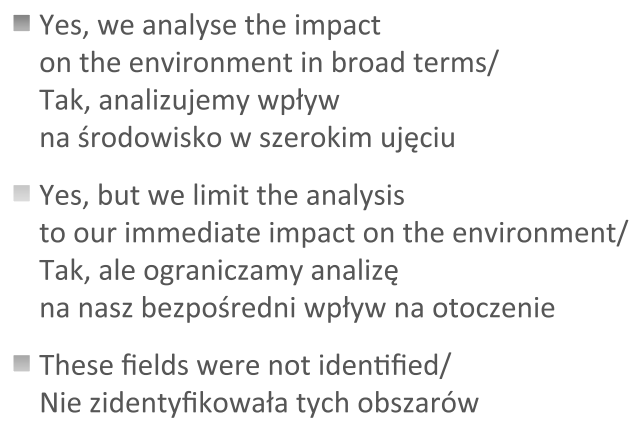

Figure 6. Analysis of the impact on the environment in the examined agribusiness companies (\%) Rysunek 6. Analiza wpływu na środowisko naturalne w badanych firmach agrobiznesu (\%) Source: own elaboration.

Źródło: badania własne.

Entrepreneurs were also asked about the aspect of reducing the consumption of materials and raw materials in the company (Figure 7). One in five respondents admitted that they did not take any actions in this regard, and only about $32 \%$ of owners claimed they were systematically trying to monitor and document the consumption of materials and raw materials in the company.
Przedsiębiorcy zostali także spytani o aspekt ograniczania zużycia materiałów i surowców w przedsiębiorstwie (rysunek 7). Co piąty badany przyznał, że nie podejmuje żadnych działań w tym zakesie a jedynie około $32 \%$ właścicieli stwierdziło, że systematycznie stara się monitorować i dokumentować zużycie materiałów oraz surowców w firmie.
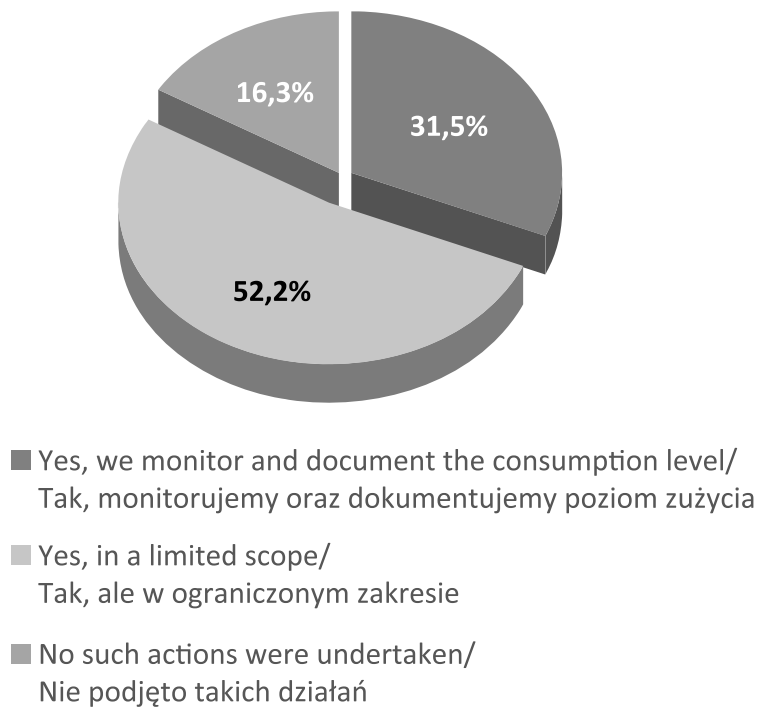

Figure 7. Limitation of consumption of materials and raw materials in the examined agribusiness enterprises (\%) Rysunek 7. Ograniczenie zużycia materiałów i surowców w badanych przedsiębiorstwach agrobiznesu (\%)

Source: own elaboration.

Źródło: badania własne. 
Entrepreneurs were also asked about their policies and activities regarding fuel and energy consumption (Figure 8). Every third respondent acknowledged that the company monitors fuel consumption or energy consumption to make further savings. In turn, more than $14 \%$ of the examined owners do not take any steps at all in order to control or monitor the use of fuels and energy.
Przedsiębiorcy zostali również spytani o ich politykę i działania względem zużycia paliw i energii (rysunek 8). Co trzeci ankietowany przyznał, że w przedsiębiorstwie monitorowane jest zużycie paliwa czy też energii w celu podejmowania dalszych działań oszczędnościowych. Z kolei ponad 14\% badanych właścicieli w ogóle nie podejmuje żadnych kroków, aby kontrolować czy nadzorować zużycie paliw i energii.
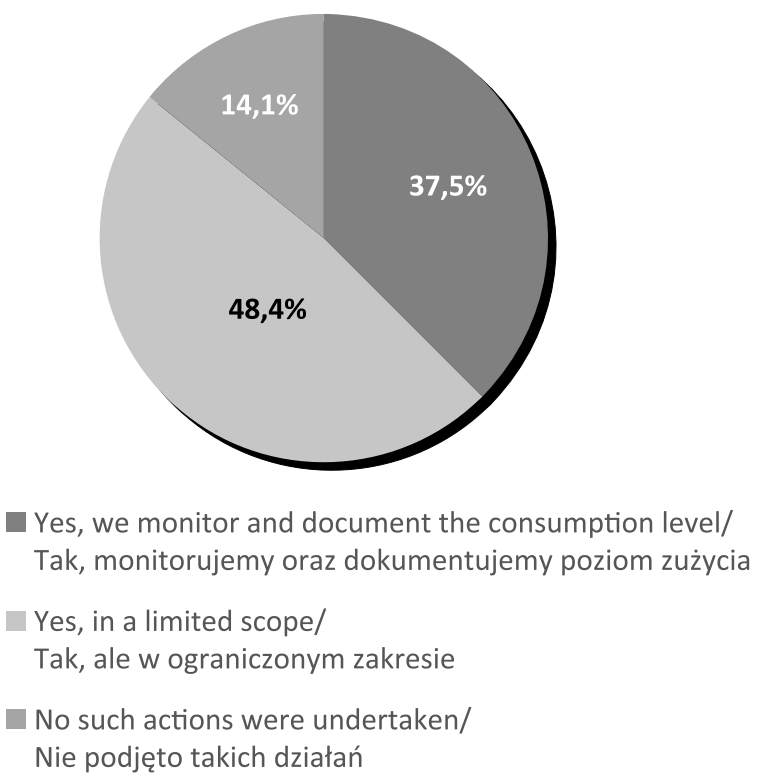

Figure 8. Limitation of fuel and energy consumption in the examined agribusiness enterprises (\%) Rysunek 8. Ograniczenie zużycia paliw i energii w badanych przedsiębiorstwach agrobiznesu (\%) Source: own elaboration.

Źródło: badania własne.

When it comes to the examined companies, only $28 \%$ confirmed that they were trying to monitor, document and reduce water consumption (Figure 9).
W przypadku badanych przedsiębiorstw, tylko $28 \%$ potwierdziło, że stara się monitorować, dokumentować oraz ograniczać zużycie wody (rysunek 9).

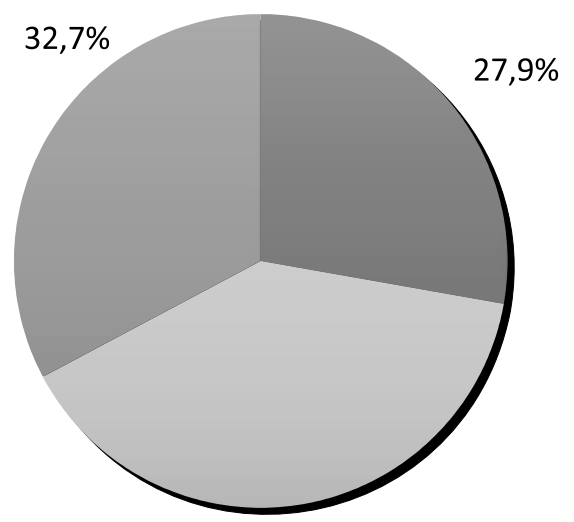

$39,4 \%$
Yes, we monitor and document the consumption level/

Tak, monitorujemy oraz dokumentujemy poziom zużycia

Yes, in a limited scope/

Tak, ale w ograniczonym zakresie

No such actions were undertaken/ Nie podjęto takich działań

Figure 9. Limitation of water consumption in the examined agribusiness enterprises (\%)

Rysunek 9. Ograniczenie zużycia wody w badanych przedsiębiorstwach agrobiznesu (\%)

Source: own elaboration.

Źródło: badania własne.

It is certainly worrying that every third respondent admitted that they did not take any steps towards limitation and saving water. No account is taken to aspects that come from the need for heating of water or discharging wastewater.
Na pewno niepokojące jest to, że co trzeci badany przyznał, że nie podejmuje żadnych działań w kierunku ograniczania i oszczędności wody. Nie bierze się także pod uwagę aspektów wynikających z potrzeby jej ogrzewania czy też odprowadzania ścieków. 


\section{Conclusions}

The research confirms the very common view that micro enterprises have a minimal interest in implementing basic social responsibility standards in the "natural environment" area. The situation is slightly better in the case of small and medium enterprises.

Pro-environmental activities are more often undertaken by companies from the manufacturing sector, especially from the agricultural section and from commercial companies rather than from transport companies. It may be worrying that the examined companies reduce to a small extent the use of materials and raw materials, including water, which is becoming increasingly scarce.

Pro-environmental activities, especially in the agribusiness sector, should be promoted, highlighting the range of benefits that can be achieved through these activities, such as improving relationships with the local community, increasing employees' motivation, and increasing customers' loyalty. The results show that business entities are not fully aware of these benefits, and perhaps with some caution are concerned with the costs that must be borne in order to apply these activities in economic practice.

Taking into account the above results, it seems to be most appropriate to continue research on the implementation of environmental policy in the SME sector of the agribusiness realm. The issue of cooperation of small and medium-sized businesses entities with external partners, mainly suppliers, is an important element in further analyses of the natural environment area. Putting them in line with ecological issues should in the future become a standard among companies promoting and implementing the concept of CSR.

\section{Wnioski}

Przeprowadzone badania potwierdzają dość często spotykaną opinię, iż mikro przedsiębiorstwa wykazują minimalne zainteresowanie wdrażaniem podstawowych standardów społecznej odpowiedzialności w obszarze „środowisko naturalne”. Nieco lepiej wygląda sytuacja $\mathrm{w}$ odniesieniu do przedsiębiorstw małych i średnich.

Działania prośrodowiskowe częściej podejmują przedsiębiorstwa z branży przetwórstwa przemysłowego, zwłaszcza z sekcji rolnej oraz firmy handlowe aniżeli przedsiębiorstwa zajmujące się transportem. Niepokoić może to, iż badane przedsiębiorstwa w niewielkim zakresie ograniczają zużycie materiałów i surowców, między innymi wody, która staje się coraz częściej surowcem deficytowym.

Na pewno powinno się promować w coraz większym zakresie działania prośrodowiskowe, zwłaszcza w firmach z sektora agrobiznesu, podkreślając szereg korzyści możliwych do osiągnięcia dzięki tym działaniom, takich jak poprawa relacji ze społecznością lokalną, większa motywacja pracowników oraz zwiększenie lojalności klientów. Przedstawione w opracowaniu wyniki pokazują, że podmioty gospodarcze $\mathrm{w}$ pełni nie dostrzegają tych korzyści, być może także z pewną ostrożnością podchodzą do kosztów, które na pewno trzeba ponieść, żeby te działania zastosować w praktyce gospodarczej.

Biorąc pod uwagę powyższe wyniki, wydaje się jak najbardziej zasadne kontynuowanie badań w aspekcie wdrażania polityki środowiskowej $\mathrm{w}$ sektorze MSP ze sfery agrobiznesu. Bardzo ważnym elementem $\mathrm{w}$ trakcie dalszych analiz dotyczących obszaru środowiska naturalnego musi być kwestia współpracy małych i średnich podmiotów gospodarczych z partnerami zewnętrznymi, głównie dostawcami. To stawianie im wymagań związanych z kwestiami ekologicznymi powinno w przyszłości stawać się standardem pośród przedsiębiorstw promujących oraz wdrażających koncepcję społecznej odpowiedzialności (CSR).

\section{References/Literatura:}

1. Banerjee S. (2008), Corporate Social Responsibility: the good, the bad and the ugly. Critical Sociology, Nr 34, s. 51-78.

2. Dziennik Ustaw 2001r., Nr 62, Poz. 627.

3. EN ISO 14001:20004 pkt. 3.12.

4. Garriga E., Mele D. (2004), Corporate Social Responsibility theories - mapping the territory. Journal of Business Ethics, Nr 53, s. 51-68.

5. Kapusta F. (2006), Przedsiębiorczość. Teoria i praktyka. Forum Naukowe, Poznań-Wrocław.

6. Lewicka-Strzełecka A. (2006), Odpowiedzialność moralna w życiu gospodarczym. IFiS PAN, Warszawa.

7. Nahotko S. (2002), Podstawy zarządzania ekologicznego przedsiębiorstw. Oficyna Wydawnicza Ośrodka Postępu Organizacyjnego, Bydgoszcz.

8. Ocieczek W., Gajdzik B. (2010), Społeczna odpowiedzialność przedsiębiorstw produkcyjnych. Wydawnictwo Politechniki Śląskiej, Gliwice.

9. Promoting a European Framework for Corporate Socjal Resposibility - Green Paper, COM (2001) 366 final, Bruksela 2001.

10. Ratajczak M., Wołoszyn J., Stawicka E. (2012), Społeczna odpowiedzialność małych $i$ średnich przedsiębiorstw agrobiznesu z obszarów wiejskich. Wydawnictwo SGGW, Warszawa.

11. Ratajczak M. (2016), Ocena wybranych działań na rzecz środowiska naturalnego podejmowanych przez przedsiębiorstwa agrobiznesu w ramach koncepcji CSR. Prace Naukowe Uniwersytetu Ekonomicznego we Wrocławiu, Wrocław, Nr 419, s. 167-177.

12. Smędzik K. (2009), Koncentracja przedsiębiorstw agrobiznesu w województwie wielkopolskim. Roczniki Ekonomiczne Kujawsko - Pomorskiej Szkoły Wyższej w Bydgoszczy, nr 2, s. 275-287. 